Folia primatol. 1983;41:I-IV

\title{
Contents, Vol. 41, 1983
}

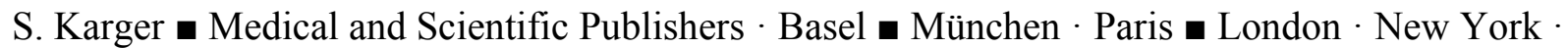
Tokyo $\cdot$ Sydney

All rights reserved. (C) Copyright 1983 by S. Karger AG,

No part of this publication may be translated into other $\quad$ P.O. Box, $\mathrm{CH}^{\wedge} \pm 009$ Basel

(Switzerland)

languages, reproduced or utilized in any form or by any Printed in Switzerland by Thür AG

Offsetdruck, Pratteln

means, electronic or mechanical, including photocopying, recording, microcopying, or by any information storage and retrieval system, without permission in writing from the publisher or, in the case of photocopying direct payment of a specified fee to the Copyright Clearance Center (see 'Information for Readers and Subscribers').

Index Vol. 41,1983

No. 1-2 Alloparental Behavior in Wild Chimpanzees of the Mahale Mountains, Tanzania Nishida, T 1

Daily Ranging Behavior of Red Colobus (Colobus badius tephrosceles) in Kibale Forest, Uganda

Isbell, L.A 34

Postcranium of Adapis parisiensis and Leptadapis magnus (Adapiformes, Primates). Adaptational and Phylogenetic Significance

Dagosto, M 49

Upper Dentition of Ekgmowechashala (Omomyid Primate) from the John Day Formation, Oligo-Miocene of Oregon

Rose, K.D.; Rensberger, J.M 102

Variation and Homology of the Primate Hypoconulid

Swindler, D.R 112

Taste Thresholds for Tryptophan in Seven Nonhuman Primate Species

Hobi, G.; Glaser, D 124

Hematology of the Lesser Mouse Lemur (Microcebus murinus). A Preliminary Study

Der Goukassian, $\mathrm{Ph} 129$

The Banded Karyotypes of Macaca fuscata Compared with Cercocebus aterrimus

Stanyon, R.; Ardito, G.; Lamberti, L.; Bigatti, P 137

Some Histological Aspects of the Palmar Digital Pads in the Vervet Monkey

Kimani, J.K 147

Book Review 156

No. 3-4 Patterns of Range Use by the Green Monkey, Cercopithecus sabaeus, at Mt. Assirik, 


\section{Senegal}

Harrison, M.J.S 157

Time Budgets and Consortships in Olive Baboons (Papio anubis)

Bercovitch, F.B 180

Effect of Estradiol-Treated Females on All-Female Groups of Rhesus Monkeys during the Transition between the Nonbreeding and Breeding Seasons

Ruiz de Elvira, M.C.; Herndon, J.G.; Collins, D.C 191

Body Weight Changes throughout Pregnancy in the Common Marmoset Callithrix jacchus Lunn, S.F 204

Qualities and Drawbacks of Radiotransmitted Vocalizations of Monkeys through Laryngophones: New Perspectives in Analysis

Gautier, J.-P 218

IV

Index

A New Genus and Species of Adapid Primate from the Middle Eocene of Alsace, and a New Genus for 'Adapis' ruetimeyeri Stehlin, 1912

Tattersall, I.; Schwartz, J.H 231

New Primate Fossils from Late Oligocene (Colhuehuapian) Localities of Chubut Province, Argentina

Fleagle, J.G.; Bown, T.M 240

Quelques remarques à propos d'un humérus d'hominoïde pliocene provenant de Chemeron (bassin du lac Baringo, Kenya)

Senut, B 267

Morphology of the Interorbital Region of Saimiri sciureus

Maier, W 277

Author Index 304

Announcement 